Nr 1(70), 2021, s. 209-226

https://doi.org/10.12797/Politeja.18.2021.70.16

\author{
Bartłomiej Secler (D) \\ Uniwersytet im. Adama Mickiewicza w Poznaniu \\ bartlomiej.secler@amu.edu.pl
}

\title{
NARRACJE ALTERNATYWNE I MARGINALNE W UCHWAŁACH ROCZNICOWYCH SEJMU \\ I SENATU RZECZYPOSPOLITEJ POLSKIEJ \\ W LATACH 2009-2019
}

\section{PRZYKŁAD UCHWAŁ UPAMIĘTNIAJĄCYCH 70. I 80. ROCZNICĘ WYBUCHU II WOJNY ŚWIATOWEJ ${ }^{1}$}

ABSTRACT Alternative and Marginal Narrations in the Anniversary Resolutions of the Sejm and Senate of the Republic of Poland in 2009-2019. Example of Resolutions Commemorating the 70th and 80th Anniversaries of the Outbreak of the Second World War

Historical anniversaries generate breakthroughs, mark systemic and political turns, and remind us of the events and characters from the past. The subject of the article are the anniversary resolutions of the Sejm and the Senate of the Republic of Poland, which I define as a tool for shaping the politics of memory and collective memory that are one of the forms of commemorating the past and serving the political authorities as means for its interpretation. I assume that the choice of anniversaries and historical figures that deserve to be commemorated is dictated by the ideological and political orientation of political parties and groups. In the above context, it is worth asking the question - referring to the title of the article - should the anniversary resolutions of the Sejm and the Senate of the Republic of Poland, their form, content, as well as way of proceeding and adopting them be considered as important and momentous narratives, or rather as alternative and marginal ones? The considerations will be illustrated with ex-

\footnotetext{
Artykuł powstał w ramach projektu „Miejsce i rola uchwał rocznicowych Sejmu i Senatu RP w polskiej polityce pamięci” finansowanego przez Narodowe Centrum Nauki. OPUS 13 nr rej. 2017/25/B/ HS5/01425.
} 
amples of resolutions adopted on the occasion of the 70th and 80th anniversaries of the outbreak of the Second World War.

Keywords: anniversary resolution, politics of memory, post-memory, collective memory, Second World War, commemoration

Słowa kluczowe: uchwała rocznicowa, polityka pamięci, postpamięć, pamięć zbiorowa, II wojna światowa, upamiętnienie

\section{PRZEDMIOT ROZWAŻAŃ}

Problematyka niniejszego artykułu poświęcona jest uchwałom rocznicowym Sejmu i Senatu Rzeczypospolitej Polskiej podjętym w latach 2009-2019². Definiuję je jako narzędzia kształtowania polityki pamięci i pamięci zbiorowej. Nadto są one jedną $\mathrm{z}$ form upamiętniania przeszłości, rocznic historycznych oraz bohaterów narodowych. Uchwały rocznicowe służą władzy państwowej (politycznej) w zakresie interpretacji przeszłości, eksponowania oraz podkreślania roli określonych wydarzeń historycznych, jak również kształtowania świadomości historycznej polskiego społeczeństwa ${ }^{3}$. Niejednokrotnie, ze względu na przedmiot i treść, inicjatywy uchwałodawcze są zarzewiem sporów i konfliktów - w wymiarze polityki wewnętrznej czy międzynarodowej4. W znaczeniu formalnym (prawnym), tj. w regulaminach Sejmu i Senatu RP, uchwały, które nazywam rocznicowymi, określone są jako uchwały okolicznościowe. Należy jednak odnotować, że katalog uchwał okolicznościowych jest znacznie szerszy i nie dotyczy tylko aktów upamiętniających - w kontekście rocznicowym - postacie i wydarzenia z przeszłości. Przedmiotowy rodzaj uchwały okolicznościowej nie jest aktem normatywnym i aktem stosowania prawa, niemniej stanowi część „szerszej kategorii porządku prawnego". Uchwały, o których tu mowa, są symbolicznymi, niewiążącymi i niewładczymi formami parlamentarnej ekspresji ${ }^{5}$.

Zakładając powyższe, jak również nawiązując do tematyki konferencji naukowej (niniejszy artykuł jest bowiem tekstem pokonferencyjnym): „Oblicza postpamięci 4:

2 Okres obejmuje VI (2007-2011) i VIII (2015-2019) kadencję Sejmu RP oraz VII (2007-2011) i IX (2015-2019) kadencję Senatu RP. Należy jednak wskazać, że uchwały, o których tu mowa, były podejmowane we wszystkich kadencjach Sejmu i Senatu RP po 1989 r.

3 B. Secler, Odzyskanie niepodlegtości w uchwatach rocznicowych Sejmu i Senatu RP, [w:] Polska po latach niewoli, red. R. Kowalczyk, Łomża 2018, s. 347. Należy tu także zaznaczyć, że w jednym ze swoich tekstów Lech M. Nijakowski pisze o uchwałach sejmowych jako mechanizmie polityki pamięci. Por. L.M. Nijakowski, Uchwaty sejmowe jako mechanizm polityki pamięci, „Przegląd Humanistyczny” 2017, vol. 61, nr 2, s. 89-103.

4 Por. B. Secler, Konfliktowe rocznice - wymiar międzynarodowy polskiej polityki pamięci na przyktadzie wybranych uchwat rocznicowych Sejmu Rzeczypospolitej Polskiej, „Przegląd Humanistyczny” 2017, vol. 61, nr 2, s. 115-134.

5 G. Maroń, Uchwaty okolicznościowe Senatu w polskim porzadku prawnym, „Przegląd Prawa Konstytucyjnego" 2014, nr 3, s. 253-273. 
Narracje alternatywne i marginalizowane" (Uniwersytet Jagielloński w Krakowie, 22-23 października 2020 r.), chciałbym postawić pytanie o charakter analizowanych w niniejszym tekście uchwal - czy z punktu widzenia władzy, biorąc pod uwagę formę, treść, sposób procedowania i podejmowania tych uchwał, są to narracje alternatywne i marginalne. Chciałbym zaznaczyć, przyjmując, że uchwała jest narzędziem władzy i formą parlamentarnej ekspresji, iż nie rozstrzygam tu, na ile analizowane uchwały kształtują pamięć zbiorową czy świadomość historyczną społeczeństwa. Wymagałby to bowiem przeprowadzenia szerokich badań empirycznych. Zakładam jednak, że jednym z celów uchwał parlamentarnych, traktowanych jako mechanizm polityki pamięci $i^{6}$, jest polityczna wola kształtowania wizji przeszłości i pamięci zbiorowej.

I drugie wyjaśnienie w odniesieniu do tytułu i celu tego artykułu: pod pojęciem narracji alternatywnej rozumiem narrację przeciwstawiającą się temu, co tradycyjne, oficjalnie uznane, stojące w opozycji do dotychczasowej retoryki. Często w debatach i sporach o przeszłość, dla przykładu tych o zabarwieniu politycznym, formułowane są tezy o próbach pisania historii na nowo przez oponentów politycznych. Z kolei narracje marginalne definiuję jako nieistotne, o niewielkim znaczeniu dla kształtowania tożsamości i pamięci wspólnoty narodowej, świadomości historycznej społeczeństwa. Zakładam nadto, że wybór rocznic historycznych zasługujących na upamiętnienie $\mathrm{w}$ formie uchwały podyktowany jest nie tylko rocznicowym kalendarzem, ale także, niekiedy przede wszystkim, orientacją ideologiczno-polityczną partii i ugrupowań politycznych aktualnie sprawujących władzę. W tym kontekście zasadne są również pytania o motywy podejmowania uchwał rocznicowych, ich treść oraz znaczenie polityczne i społeczne. Warto też wspomnieć o problemie zawłaszczania rocznic historycznych i/lub polityce niepamięci.

Ramy teoretyczne i siatkę pojęciową niniejszego artykułu wyznaczają naukowe koncepcje polityki pamięci i postpamięci. W przypadku pierwszej należy odnotować, że jest ona naturalnie powiązana $\mathrm{z}$ władzą $\mathrm{i}$ jej dążeniem do kształtowania pamięci zbiorowej. To, co ludzie pamiętają, tudzież jakie emocje się z tym wiążą, przekłada się na ich postawy, decyzje oraz zachowania. Wokół ważnych wydarzeń toczy się zatem nieustanna walka o ich interpretację ${ }^{7}$. Jak zauważa Barbara Szacka, to postaci i wydarzenia z przeszłości rozumiane jako symbole, postawa i wartości w obrębie pamięci społecznej konstruują specyficzny język grupy, który staje się jej znakiem rozpoznawczym ${ }^{8}$. $\mathrm{Z}$ kolei $\mathrm{w}$ odniesieniu do postpamięci, terminu zaproponowanego przez Marianne Hirsch' ${ }^{9}$, warto zwrócić uwagę na możliwość zastosowania tego pojęcia w badaniach nad pamięcią zbiorową ${ }^{10}$. Postpamięć kształtuje przede wszystkim tożsamość jednostki,

L.M. Nijakowski, Uchwaty sejmowe..., s. 89.

L.M. Nijakowski, Polska polityka pamięci. Esej socjologiczny, Warszawa 2008, s. 48-49.

8 B. Szacka, Pamięć spoteczna a identyfikacja narodowa, [w:] Trudne sąsiedztwa. Z socjologii konfliktów narodowych, red. A. Jasińska-Kania, Warszawa 2001, s. 40-41.

9 M. Hirsch, Family Frames. Photography, Narrative and Postmemory, London 1997, passim.

10 M. Hirsch, Pokolenie postpamięci, przeł. M. Borowski, M. Sugiera, „Didaskalia. Gazeta Teatralna” 2010, vol. 18 , nr 105, s. 28-36. 
charakterystyczną dla pamięci indywidualnej. Niemniej w szerszym znaczeniu postpamięć może być także wykorzystana do kształtowania pamięci zbiorowej. Identyfikacja postpamięci grupowej daje możliwość uchwycenia i zdiagnozowania roli empatycznego przeżywania doświadczenia, wspólnego pewnym grupom, przez inne grupy, które to doświadczenie przepracowaty, zracjonalizowaty i wytworzyty na tej podstawie wartości, wtaczone do wtasnej narracji o rzeczywistości. Podobnie jak w wypadku oddziatywania postpamięci na tożsamość jednostek znajduje tu zastosowanie metafora śladu. Pamięć gromadzi wszystko, co zapisuje się w niej w przesztości; w postpamięci natomiast funkcjonuja treści nieobojętne, wciąż żywe (traumatyczne, bolesne lub - po prostu - z jakichśs powodów szczególnie istotne). Postpamięć jest zatem przestrzenią dziatania śladu, który $w$ dużej mierze decyduje o konstrukcji tożsamości (zarówno jednostki, jak i grupy) ${ }^{11}$ - czytamy w leksykonie kultury pamięci Modi memorandi.

Niniejsze rozważania, oparte na nakreślonych wyżej założeniach, zostaną w dalszej części tekstu zobrazowane przykładami uchwał rocznicowych Sejmu i Senatu RP upamiętniającymi 70. i 80. rocznicę wybuchu II wojny światowej (odpowiednio 2009 i 2019 rok). Wybór problematyki uchwał podyktowany jest przekonaniem, mającym chociażby oparcie w polskich badaniach opinii, że pamięć o II wojnie światowej zajmuje istotne miejsce w pamięci zbiorowej polskiego społeczeństwa i świadomości historycznej Polaków ${ }^{12}$ - jest zatem treścia nieobojętna, wciąż żywą. Nadto pamięć II wojny światowej odgrywa znaczącą rolę w stosunkach między państwami i narodami ${ }^{13}$.

Analiza wyżej wskazanych uchwał zostanie poprzedzona refleksją na temat upamiętniania rocznic historycznych i ich politycznych implikacji.

\section{ŚWIĘTA PAMIĘCI}

Anna Wolff-Powęska w jednym z uniwersyteckich wykładów otwartych postawiła pytanie Kto wtada nasza pamięcia zbiorowa ? ${ }^{14}$. W odpowiedzi uczona zwróciła uwagę m.in. na rolę nośników pamięci, które kształtują kulturę historyczną i polityczną, jak również legitymizują ustrój polityczny. Ważne jest bowiem nie tylko to, co pamiętamy, ale także jak pamiętamy. Władza, wykorzystując medium, jakim są święta pamięci, może władać zbiorową pamięcią i wyobraźnią. Podstawową funkcją świąt pamięci jest poczucie przynależności, więzi ze wspólnotą, dają one także poczucie kontynuacji dziejów, chociażby poprzez akty symboliczne, którymi są rytuały i obrzędy ${ }^{15}$. Są one usystematyzowane

11 K. Kaniowska, Postpamięć, [w:] Modi memorandi. Leksykon kultury pamięci, red. M. Saryusz-Wolska, R. Traba, współpr. J. Kalicka; rada nauk. P. Czapliński i in., Warszawa 2014, s. 391.

12 Szerzej (dla przykładu): P.T. Kwiatkowski, L.M. Nijakowski, B. Szacka, A. Szpociński, Między codziennością a wielką historią. Druga wojna światowa w pamięci zbiorowej spoteczeństwa polskiego, GdańskWarszawa 2010.

13 Tamże, s. 7.

14 A. Wolff-Powęska, Kto wtada nasza pamięcia zbiorową?, [online] http://usf.amu.edu.pl/filmoteka/ wykłady-uniwersyteckie/wykład-49-prof-anna-wolff-powęska-kto-włada-naszą-pamięcią-zbiorową, 21 IX 2020. 
i powtarzalne, dzięki czemu nadają sens rzeczywistości, łącząc tym samym teraźniejszość z przeszłością ${ }^{16}$. Marcin Napiórkowski nazywa to synchronizacja pamięciowa ${ }^{17}$. W innym miejscu A. Wolff-Powęska pisze, że święta pamięci stanowią plaszczyznę, na której spotykają się elementarne interesy i potrzeby wtadców oraz poddanych, rządów oraz obywateli, pañstw i spoteczeństw. Narody i ich polityczni przedstawiciele potrzebuja symboli. [...] Dni pamięci stanowia najbardziej esencjonalny polityczny symbol państwa. Przy ich pomocy wywotywane sa emocje i prezentowane sa trési polityczne ${ }^{18}$. W tym kontekście można chociażby odnotować wykorzystywanie takich narzędzi, jak oficjalne przemówienia, wieńce składane na miejscach pamięci, akty przebaczenia i pojednania czy - będące przedmiotem tego szkicu - uchwały rocznicowe Sejmu i Senatu RP.

Święta i związane z nimi obrzędy są ważnym czynnikiem tworzenia, podtrzymywania i utrwalania stosunków społecznych. Nie należy także zapominać o funkcji kreowania określonych w danej grupie wzorców zachowań, integrujących społeczność oraz wiążących jej wewnętrzną strukturę. Ewolucja obrzędowości - już od czasów starożytnych cywilizacji - w społeczeństwie, narodzie, państwie, związana jest z przeświadczeniem, iż działania takie rozwijają w jednostkach wrażliwość na elementy symbolicznej tożsamości wspólnoty, co z kolei kształtuje pamięć zbiorową i świadomość historyczną. Dość wspomnieć, za A. Wolff-Powęską, że celebracja rocznic i świąt narodowych pełni funkcję kompensacyjną, tj. dla jednych demonstracja obrzędowości narodowej jest niezbędnym elementem tożsamości historycznej, dla innych zaś podejrzanym dyktatem kalendarza, triumfem przymusowego i cyklicznego powtarzania świąt narodowych nad krytycznym namysłem nad sensem i znaczeniem określonych wydarzeń historycznych ${ }^{19}$.

W powyższym kontekście należy zauważyć, że pamięć była i jest przedmiotem władzy. Jej kształtowanie w wymiarze zbiorowym poprzez sięganie w retoryce politycznej po argumentację historyczną ma istotne znaczenie zarówno w perspektywie rocznicowych rytuałów i kommemoratywnych aktów, jak i bieżącej praktyce politycznej przejawiającej się w kreowaniu polityki pamięci i rozmaitych jej strategii. Dla przykładu działania takie można dostrzec w budowaniu nowej tożsamości państwa, która oparta jest na występowaniu w roli ofiary, a nie sprawcy, wybielaniu swojego wizerunku, relatywizowania winy, podejmowaniu prób rewizji historii, jej zawłaszczaniu i nacjonalizacji czy błędnej interpretacji faktów historycznych wynikających z ignorancji, niewiedzy lub po prostu złej woli, partykularnego interesu. Selekcja postaci i wydarzeń godnych upamiętnienia według klucza politycznego takiej czy innej władzy generuje spory i podziały polityczno-społeczne oraz wpływa destrukcyjnie na tożsamość narodową. Tworzy

16 Za: I. Main, Trudne świętowanie. Konflikty wokót obchodów świąt pansstwowych i kościelnych w Lublinie (1944-1989), Warszawa 2004, s. 22. Por. D.I. Kertzer, Ritual, Politics and Power, New Heaven-London 1988, s. 9.

17 M. Napiórkowski, Powstanie umartych. Historia pamięci 1944-2014, Warszawa 2016, s. 150.

18 A. Wolff-Powęska, Rocznice historyczne jako medium polityki pamięci, [w:] Na obrzeżach polityki. Praca zbiorowa. Cz. 7, red. M. Kosman, Poznań 2009, s. 34.

19 A. Wolff-Powęska, Polskie spory o historię i pamięć. Polityka historyczna, „Przegląd Zachodni” 2007, nr 1, s. 5 . 
się bowiem dychotomiczny podział na „nasze” $\mathrm{i}$ „wasze” wydarzenia historyczne oraz „naszych” i ,waszych” bohaterów narodowych. Za Janem Assmannem, przedstawiającym rozważania o aliansie pamięci i władzy, rzec można, iż silnym stymulatorem pamięci jest właśnie władza, która potrzebuje legitymizacji w aspektach retrospektywnym i prospektywnym ${ }^{20}$. Pierwszy odnosi się potrzeby usankcjonowania pochodzenia władzy, a drugi do zapewnienia sobie „nieśmiertelności” w pamięci zbiorowej poprzez odpowiednią narrację w podręcznikach, muzea, pomniki, nazwy ulic, badania naukowe czy polityczne akty w postaci uchwał rocznicowych.

Uchwały rocznicowe wpisują się w szeroki zakres upamiętnienia przeszłości, tj., co zostało już wyżej odnotowane, wydarzeń historycznych oraz zasłużonych dla narodu i państwa postaci. Należy podkreślić, że w ostatnich dwóch dekadach Sejm i Senat RP nader często sięgały po to narzędzie polityki pamięci, narażając się niekiedy na krytykę, iż zbyt duża liczba podejmowanych uchwał negatywnie przekłada się na ich rzeczywistą wartość dla kształtowania pamięci zbiorowej. Dla przykładu w minionej, VIII kadencji Sejmu RP izba podjęła 119 uchwał rocznicowych. Obok upamiętnienia takich wydarzeń, jak 75. rocznica wybuchu powstania warszawskiego (2019), 75. rocznica powstania w getcie warszawskim (2018), 60. rocznica zapoczątkowania procesu integracji europejskiej (2017), 35. rocznica tragicznych wydarzeń w Kopalni Węgla Kamiennego „Wujek” (2016), uczczono także 150. rocznicę powstania Towarzystwa Gimnastycznego „Sokól” (2017), 100. rocznicę objawień fatimskich (2017), 100. rocznicę inauguracji polskiej awangardy (2017) czy 100. rocznicę powołania Polskiego Komitetu Ratunkowego Dzieci Dalekiego Wschodu oraz pomocy dla nich ze strony cesarzowej Japonii (2019). Istotnym dla wzrostu liczby sejmowych i senackich inicjatyw uchwałodawczych był rok 2000. W tym czasie odnotowuje się nie tylko erupcję inicjatyw w zakresie polityki pamięci, ale także sporów o przeszłość. Paweł Machcewicz słusznie zauważa, że Polacy zaczęli wtedy więcej uwagi poświęcać historii, gdyż w latach 90 . XX wieku dokonała się juz bolesna transformacja ustrojowa i gospodarcza, która pochtaniata gros uwagi zwyktych ludzi [...]. Gtębokie zmiany w codziennej egzystencji [...] nie sprzyjaty refleksji o przesztości. [...] Dla większości elit politycznych i środowisk opiniotwórczych w pierwszej dekadzie niepodlegtej Polski istotniejsze od rozrachunków historycznych zdawaty się zadania związane z reformowaniem gospodarki, przebudowa państwa, zmiana międzynarodowego potożenia Polski ${ }^{21}$. Nadto znaczenie miało także powołanie w 2000 r. Instytutu Pamięci Narodowej.

W perspektywie nakreślonych wyżej założeń i zasygnalizowanych treści zwróćmy uwagę na wybrane uchwały Sejmu i Senatu RP upamiętniające 70. i 80. rocznicę wybuchu II wojny światowej.

20 J. Assmann, Pamięć kulturowa. Pismo, zapamiętywanie i polityczna tożsamość w cywilizacjach starożytnych, red. R. Traba, przeł. A. Kryczyńska-Pham, Warszawa 2008, s. 85-86. 


\section{PARLAMENTARNE NARRACJE UPAMIĘTNIAJACE ROCZNICĘ WYBUCHU II WOJNY ŚWIATOWEJ}

Narrację powszechnie definiuje się jako sposób wypowiedzi, przedstawienie czy opis jakiś zdarzeń, opowiadanie. Jako kategoria badawcza narracja na trwałe wpisała się w refleksję humanistyczną ${ }^{22}$. W tym kontekście możemy chociażby wskazać na pojęcie narracji historycznej, choć - jak zauważa Andrzej Radomski - jest ono niejasne i wieloznaczne $e^{23}$. Najczęściej narracja historyczna to opowiadanie o przesztości; kompetencja, dzięki której historyk bada przesztość, a następnie tworzy o niej opowieść czy zbiór tropów i figur retorycznych ${ }^{24}$. Przyjmuję, że uchwały rocznicowe Sejmu i Senatu RP można uznać za typ narracji historycznej, opowiadania o przeszłości. Nawiązując do tytułu niniejszego artykułu i poczynionych założeń w części wstępnej, narracje te mogą mieć charakter alternatywny i marginalny. Nasuwa się zatem pytanie, czy taki charakter mają uchwały upamiętniające 70 . i 80 . rocznicę wybuchu II wojny światowej.

Historia własnego narodu i pamięć o niej stanowią fundament kształtowania tożsamości narodowej. Druga wojna światowa należy do wydarzeń, które wpłynęły na dzieje Polski, Europy i świata. W Polsce rocznica wybuchu wojny pełniła i pełni różne funkcje. Początkowo podnosiła morale żołnierzy i kształtowała przekonanie o bohaterstwie polskiej armii. Nadto jednoczyła Polaków w przeżywaniu tragicznych wydarzeń. Później pamięć o wojnie modelowała tożsamość, świadomość historyczną, kommemoratywne narracje zaś czyniły żywym to wydarzenie i bohaterskie czyny zwycięzców wojny. Tym samym w pamięciowych opowieściach i debatach o wojnie pojawiły się głosy o sprawcach i ofiarach, winie i przebaczeniu, okraszone często licznymi świadectwami o bolesnych i traumatycznych przeżyciach pokolenia wojny - ważnymi także z punktu widzenia postpamięciowej narracji. Biorąc po uwagę powyższe, należy sądzić, że uchwały sejmowe i senackie nie są narracjami marginalnymi (nieistotnymi). Mówią bowiem o sprawach doniosłych, ważkich, fundamentalnych. Są także istotne dla prowadzonej przez państwo polityki pamięci, które poprzez tego typu akty narzuca określoną wizję przeszłości, choć czyni to niekiedy przy wykorzystaniu narracji alternatywnych, szybko stających się konfrontacyjnymi. Pojawiają się wówczas zarzuty o odejście od prawdy historycznej na rzecz prawdy politycznej, rewizjonizm historyczny, fałszowanie przeszłości, politykę niepamięci, tworzenie mitów itd.

W 2009 r. przypadały rocznice wielu ważnych dla polskiej historii wydarzeń. Pod względem ich upamiętnia rok ten został jednak zdominowany przez 70. rocznicę wybuchu II wojny światowej - odbyły się liczne seminaria i konferencje naukowe, jak również oficjalne, państwowe uroczystości, których planowaniem zajął się, powołany przez ówczesnego premiera Donalda Tuska, Komitet Organizacyjny do spraw Przygotowania Obchodów 70. Rocznicy Wybuchu II Wojny Światowej oraz 20. Rocznicy

\footnotetext{
22 Szerzej: P. Kulas, Narracja jako przedmiot badań oraz kategoria teoretyczna w naukach spotecznych, „Kultura i Społeczeństwo” 2014, nr 4, s. 111.

23 A. Radomski, Badanie narracji historycznej: próba konceptualizacji kulturoznawczej, „Annales Universitatis Mariae Curie-Skłodowska. Sectio F” 2001, vol. 56, s. 212.

$24 \quad$ Tamże, s. 212.
} 
Odzyskania Wolności i Upadku Komunizmu w Europie Środkowej. W Sejmie RP inicjatywę uchwałodawczą w 70. rocznicę wybuchu II wojny światowej ${ }^{25}$ przedłożyło Prezydium Sejmu po uzyskaniu jednolitej opinii Konwentu Seniorów. Projekt został skierowany do pierwszego czytania na posiedzeniu Sejmu RP 28 sierpnia 2009 r. Inicjatywę przedstawił Marszałek Sejmu Bronisław Komorowski, który zaproponował, by izba przyjęła uchwałę przez aklamację, co też miało miejsce. Posłowie oddali hołd ofiarom i bohaterom wojny - żołnierzom, ludności cywilnej oraz wszystkim tym, którzy walczyli w imię wolności Ojczyzny i współobywateli. Sejm RP przypomniał w uchwale genezę wydarzenia, wskazując na winę hitlerowskich Niemiec, jak również pakt Ribbentrop-Mołotow będący preludium do 17 września 1939 r. Odnotowując liczbę ofiar, posłowie wyrazili przekonanie, że tragedia II wojny światowej otworzyła w dziejach Europy nowy rozdział, a dzięki pojednaniu pokój $i$ wspótpraca staty się fundamentem zjednoczonej, demokratycznej Europy. Czcząc bohaterów „okrutnej wojny”, Sejm RP zauważył, że ich ofiara stanowi swoiste memento sktaniajace nas do silnego postanowienia, iż należy uczynić wszystko co możliwe, aby już nigdy we wspótczesnym świecie wojny i konflikty zbrojne nie byty sposobem rozwiązywania sporów [...]. Jednocześnie izba wezwała, w imię pamięci ofiar, do poszanowania prawdy historycznej i przeciwstawiania się próbom rozmywania odpowiedzialności za dramat milionów obywateli Europy i świata ${ }^{26}$.

W Senacie RP złożono dwie inicjatywy uchwałodawcze. Pierwszą, w 70. rocznicę napaści przez Niemcy i Rosję na Polskę ${ }^{27}$, zaproponował senator Piotr Andrzejewski (Klub Parlamentarny Prawo i Sprawiedliwość). Autor w długim uzasadnieniu poprzedzonym przekonaniem o przemilczaniu faktów i wyrażaniu jednostronnych opinii na temat rocznicy wybuchu wojny wynikających z aktualnej polityki historycznej [Platformy Obywatelskiej - B.S.], używał argumentów o prowadzeniu przez Związek Sowiecki i III Rzeszę Niemiecką polityki eksterminacji przeciw Rzeczypospolitej, planu tępienia Narodu Polskiego, grabienia dóbr materialnych, czystek etnicznych, zbrodni wojennych i ludobójstwa $a^{28}$. Senator przekonywał słowami proponowanej uchwały, że budowa stosunków przyjaźni i wspótpracy między Naszymi Narodami winna być budowana na gruncie prawdy, wzajemnego poszanowania wolności, z która nierozerwalnie wiąże się odpowiedzialnosś za przesztość i przysztośc ${ }^{29}$. Projekt został skierowany pod obrady Komisji Ustawodawczej oraz Komisji Spraw Zagranicznych. Podobnie zresztą jak drugi z projektów ${ }^{30}$, zaproponowany przez senatora Łukasza Abgarowicza (Klub Parlamentarny

25 Projekt uchwaty w 70. rocznice wybuchu II wojny światowej, Druk nr 2291 z 28 sierpnia 2009 r., [online] http://orka.sejm.gov.pl/Druki6ka.nsf/wgdruku/2291/\$file/2291.pdf, 17 X 2020.

26 Uchwata Sejmu Rzeczypospolitej Polskiej z dnia 28 sierpnia 2009 r. w 70 . rocznicę wybuchu II wojny swiatowej, „Monitor Polski” 2009, nr 55, poz. 766.

27 Sprawozdanie Komisji Ustawodawczej oraz Komisji Spraw Zagranicznych o projekcie uchwaty w 70. Rocznice napaści przez Niemcy i Rosję na Polskę, Druk nr 642 z 8 września 2009 r., [online] http:// ww2.senat.pl/k7/dok/dr/600/642o.pdf, 17 X 2020.

Por. tamże.

29 Tamże.

30 Projekt uchwaty w 70. Rocznice wybuchu Drugiej Wojny Światowej, Druk nr 643 z 8 września 2009 r., [online] https://www.senat.gov.pl/prace/posiedzenia/tematy,222,1.html, 17 X 2020. 
Platforma Obywatelska). Projekt ten miał zdecydowanie łagodniejszy wydźwięk niż ten autorstwa senatora P. Andrzejewskiego. Mówił m.in. o wkroczeniu na terytorium Polski wojsk niemieckich, IV rozbiorze Polski, ponurym epizodzie w dziejach ludzkości, doświadczeniu przez Polaków ludobójstwa, więzień, zsytek i wysiedleñ ${ }^{31}$. Po szerokiej i wielowątkowej dyskusji nad projektami, zgłoszonymi poprawkami ${ }^{32}$ wyżej wskazane komisje wniosły o odrzucenie przez Senat RP projektu senatora Andrzejewskiego ${ }^{33}$, wnosząc jednocześnie poprawki do projektu senatora Abgarowicza ${ }^{34}$. Podczas obrad na forum plenarnym izby - 23 września 2009 r. - Senat RP odrzucił, zgodnie z sugestią połączonych komisji, projekt uchwały autorstwa senatora Prawa i Sprawiedliwości (68 głosów za odrzuceniem, 19 przeciw, 1 wstrzymujący się). W przyjętym z poprawkami projekcie senatora Abgarowicza (87 głosów „za”, bez głosów przeciwnych i wstrzymujących się) ${ }^{35}$ Senat RP przypomniał o 70. rocznicy wybuchu II wojny światowej, złożył hołd wszystkim ówczesnym obrońcom Ojczyzny i oddał cześć pamięci wszystkich jej ofiar $^{36}$. W tekście senackiej uchwały pozostawiono słowa o IV rozbiorze Polski, uzgodnionym pomiędzy agresorami i przypieczętowanym 23 sierpnia 1939 r. Paktem Ribbentrop-Mototow. W uchwale czytamy także: Zachodnia Europa przerażona okropnościami II wojny światowej nieustannie dąży do pojednania między narodami, opartego na prawdzie, pamięci tamtych strasznych zdarzeń i wzajemnym wybaczeniu win. Senat Rzeczpospolitej Polskiej wyraża wole pojednania i budowy przyjaznych stosunków również z państwami i narodami Europy Wschodniej. [...] szczególnie w stosunkach polsko-rosyjskich proces pojednania wymaga szczerych intencji i bezwzglednego poszanowania prawdy historycznej, która nie można manipulować dla doraźnych politycznych korzyści ${ }^{37}$.

Analiza treści przyjętych przez Sejm i Senat RP w 2009 r. uchwał rocznicowych w 70. rocznicę wybuchu II wojny światowej dowodzi, że podstawowym celem tych symbolicznych aktów, obok przypomnienia o wydarzeniach sprzed 70 lat, było przede wszystkim upamiętnienie ofiar i bohaterów wojny (polscy mężni żotnierze; ludność cywilna), jak również oddanie im hołdu i czci. W tym kontekście ważna jest - pojawiająca się w dyskursie o II wojnie światowej - kategoria sprawcy i ofiary, charakterystyczna chociażby dla rozliczenia z przeszłością, przebaczenia i pojednania. Odczytywać

31 Por. tamże.

32 Zapis stenograficzny (1098) ze wspólnego posiedzenia Komisji Spraw Zagranicznych (85.) oraz Komisji Ustawodawczej (227.) w dniu 22 września 2009 r., [online] http://ww2.senat.pl/k7/kom/ ksz/2009/085sz.htm, 18 X 2020.

33 Sprawozdanie Komisji Ustawodawczej i Komisji Spraw Zagranicznych (wraz z zestawieniem wszystkich wniosków) o projekcie uchwaty w 70. rocznicę napaści przez Rosję i Niemcy na Polskę, Druk nr 642 O z 22 września 2009 r., [online:] http://ie.senat.gov.pl/k7/dok/dr/600/642o-poprawiony.pdf, 18 X 2020.

34 Sprawozdanie Komisji Ustawodawczej i Komisji Spraw Zagranicznych (wraz z zestawieniem wszystkich wniosków) o projekcie uchwaty w 70. Rocznicę wybuchu Drugiej Wojny Światowej, Druk 643 z 22 września 2009 r., [online:] http://ie.senat.gov.pl/k7/dok/dr/600/643o.pdf, 18 X 2020.

35 W odnotowanych głosowaniach nie brał udziału senator P. Andrzejewski.

36 Uchwata Senatu Rzeczypospolitej Polskiej z dnia 23 września 2009 r. w 70. rocznicę wybuchu drugiej wojny światowej, „Monitor Polski” 2009, nr 63, poz. 832.

37 Tamże. 
to należy zarówno w perspektywie polskiej, jak i międzynarodowej. Aspekty te trudno uznać za narracje marginalne. Biorąc zaś pod uwagę narracje alternatywne, należy odnotować, że istnieje wyraźny rozdźwięk w stosunkach polsko-rosyjskich w zakresie polityki pamięci o II wojnie światowej (i oczywiście nie tylko na ten temat). Stąd też w analizowanych uchwałach znalazły się wezwania do poszanowania prawdy historycznej, przeciwdziałania manipulacjom i rozmywania odpowiedzialności w imię doraźnych korzyści politycznych. Odczytywałbym to jako postulat przywracania pamięci, tym bardziej że bez uznania winy, rzetelnego i wspólnego osądu popełnionych zbrodni oraz wzajemnym wybaczeniu win, trudno - jak czytamy w uchwale - pojednać się i budować przyjazne stosunki. Należy przy tym podkreślić, że motyw pojednania jest jednym z ważniejszych elementów polityki pamięci. Pojawia się on także w postpamięciowym dyskursie, szczególnie w perspektywie narracji o bólu i traumie indywidualnej oraz zbiorowej będącej konsekwencją wojennych doświadczeń.

W parlamentarnych narracjach o 70. rocznicy wybuchu II wojny uchwałodawcy za istotne uznali wykorzystanie form językowych podkreślających tragizm wojny (okrutna wojna, najbardziej ponury okres $w$ dziejach ludzkości, czaspogardy) oraz dramatyczny los Polski i Polaków. Należy przy tym zauważyć, że uchwała Senatu RP charakteryzuje się ostrzejszą retoryką niż akt przyjęty przez Sejm RP (dokonat się czwarty rozbiór Polski, obywatele Rzeczypospolitej Polskiej doświadczyli ze strony obydwu najeźdźców ludobójstwa). W kontekście analizowanej uchwały należy podkreślić, że w dyskusji nad jej ostatecznym kształtem to właśnie słowo ludobójstwo wzbudziło największą dyskusję. Zresztą nie po raz pierwszy. W 2009 r. był procedowany także projekt uchwały upamiętniającej 70. rocznicę agresji ZSRR na Polskę. Źródłem konfliktu była próba przeforsowania przez klub parlamentarny Prawa i Sprawiedliwości zapisu określającego działania sowieckiej okupacji jako ludobójstwo. Wskazywano przy tym, że nie jest to narracja alternatywna, a działanie w imię poszanowania prawdy historycznej, której nie można przemilczać ani nią manipulować. Spór o ten zapis, będący jednocześnie sporem ideowym, światopoglądowym pomiędzy Prawem i Sprawiedliwością a Platformą Obywatelską, był szeroko komentowany w polskich mediach. Miał on także rezonans międzynarodowy, tj. wpisywał się w już i tak trudne relacje na linii Warszawa-Moskwa. Uchwały Sejmu i Senatu RP upamiętniające 70. rocznicę wybuchu II wojny światowej takiego oddziaływania nie miały. Ich uchwalenie zostało tylko odnotowane przez polskie media, a zatem w dyskursie medialnym były one potraktowane marginalnie.

Kolejne uchwały upamiętniające wybuch II wojny światowej Sejm i Senat RP podjęły dekadę później - z okazji 80. rocznicy tego wydarzenia. W izbie niższej parlamentu projekt uchwały w sprawie upamiętnienia 80. rocznicy wybuchu II wojny światowej $^{38}$, zaproponowało Prezydium Sejmu po zasięgnięciu opinii Konwentu Seniorów. Uchwała z 30 sierpnia 2019 r. została przyjęta przez aklamację. Znamienne, że jej treść nie wzbudziła politycznych kontrowersji. Uwaga ta jest istotna chociażby w kontekście przejęcia przez Prawo i Sprawiedliwość kontroli nad Muzeum II Wojny Światowej, co

38 Projekt uchwaty w sprawie upamiętnienia 80. Rocznicy wybuchu II Wojny Światowej, Druk nr 3800 z 30 sierpnia 2019 r., [online] https://orka.sejm.gov.pl/Druki8ka.nsf/0/AACDE7D99ADEFC65C1258466005B30F9/\%24File/3800.pdf, 18 X 2020. 
było (i nadal jest, także wobec niedawnego „przejęcia” terenów Westerplatte) przedmiotem sporu, nie tylko politycznego ${ }^{39}$. Dość wspomnieć, że w programie Prawa i Sprawiedliwości z 2014 r. polityka pamięci (polityka historyczna) zajmowała ważne miejsce. W przedłożonej diagnozie krytykowano rządy D. Tuska, np. w odniesieniu do braku reakcji polskiego rządu na korektę niemieckiej polityki pamięci, kwestionującą - według autorów programu partii Jarosława Kaczyńskiego - prawdę historyczną oraz moralną odpowiedzialność za II wojnę światową. W dokumencie można przeczytać, że prowadzona jest polityka zmierzająca do relatywizacji winy Niemców za największe zbrodnie II wojny światowej i obciązenie nimi Polaków ${ }^{40}$. PiS krytykowało również budżetowe wsparcie dla filmu Poktosie: Za pieniądze polskich podatników propaguje się ktamliwa wizję historii Polski. Państwo, które pierwsze i za cene wielkich ofiar przeciwstawiato się zbrojnie niemieckiemu nazizmowi i jednocześnie padto ofiara sowieckiego komunizmu, jest przedstawiane jako wspótsprawca zbrodni. Fatszuje się obraz Holokaustu, który na naszych ziemiach $w$ sposób zorganizowany realizowaty organy państwa niemieckiego jednocześnie dokonując niezwykle brutalnych, krwawych i masowych represji wobec Polaków jako narodu, też majacych charakter ludobójstwa. W przypadku takich manipulacji mamy do czynienia $z$ historycznymi ktamstwami ${ }^{41}$. Już wtedy partia zapowiadała, także ustami kandydata na urząd prezydenta RP Andrzeja Dudy, że po ich dojściu do władzy polska polityka pamięci będzie aktywna, ofensywna i godna.

We wspomnianej wyżej uchwale Sejm RP przypomniał m.in. o ofiarach wojny w skali globalnej, bezmiarze ludzkiego cierpienia, stratach, które poniosła Polska, i o tym, że Polacy poddani zostali licznym represjom takim jak egzekucje, przesiedlenia, zabór mienia. [...] Na okupowanym terytorium Polski Niemcy utworzyli obozy koncentracyjne - miejsca, w których dokonywano na niespotykana wcześniej skale masowej eksterminacji ludności pochodzenia żydowskiego, ale również Polaków oraz wielu innych narodów ${ }^{42}$. Uchwałą Sejm RP uczcił pamięć obrońców Ojczyzny oraz wszystkich żotnierzy i cywilów polegtych $i$ zamordowanych w latach 1939-1945.

Projekt uchwały Senatu RP w sprawie upamiętnienia 80. rocznicy wybuchu II wojny światowej złożyła grupa senatorów PiS: Stanisław Gogacz, Marek Martynowski i Jan Żaryn ${ }^{44}$. Jej treść była bardzo podobna do propozycji przedłożonej izbie niższej parlamentu. W projekcie senackim znalazło się jednak zdanie, iż II wojna światowa była $z a-$ planowanym ludobójstwem. Podczas obrad Komisji Ustawodawczej, gdzie skierowany

39 Szerzej: P. Machcewicz, Muzeum, Kraków 2017.

40 Program PiS 2014, s. 27, [online:] http://pis.org.pl/dokumenty?page=2, 29 IX 2020.

${ }^{41}$ Tamże, s. 27. Por. także: B. Secler, Polityka historyczna VIII kadencji Sejmu RP - nowe otwarcie? Przyktad podjetych uchwat rocznicowych (listopad 2015-lipiec 2016), [w:] Na obrzeżach polityki. Praca zbiorowa. Cz. 11, red. M. Kosman, Poznań 2017, s. 61-72.

42 Uchwata Sejmu Rzeczypospolitej Polskiej z dnia 30 sierpnia 2019 r. w sprawie upamiętnienia 80. Rocznicy wybuchu II Wojny Ŝiatowej, „Monitor Polski” 2019, poz. 846.

43 Tamże.

44 Projekt uchwaty w sprawie upamiętnienia 80. rocznicy wybuchu II Wojny Światowej, Druk nr 1288 z 30 sierpnia 2019 r., [online:] https://www.senat.gov.pl/download/gfx/senat/pl/senatdruki/10483/ druk/1288.pdf, 18 X 2020. 
został projekt uchwały, senator J. Żaryn podkreślił, że osiemdziesiata rocznica wybuchu II wojny światowej to rocznica na tyle ważna, bardzo ważna - nie dyskutujemy z tym - że uznaliśmy, iz Sejm i Senat powinny się w tej sprawie porozumieć. Ta uchwata jest efektem pewnego miksu intelektualnego, który zostat dokonany między Sejmem a Senatem oraz formacja Prawa i Sprawiedliwości ${ }^{45}$. Po wprowadzaniu poprawek nieingerujących zasadniczo w treść i wydźwięk uchwały komisja jednomyślnie przyjęła projekt, rekomendując Senatowi RP jego uchwalenie ${ }^{46}$. Podczas obrad plenarnych przed głosowaniem nad przyjęciem uchwały rocznicowej do projektu raz jeszcze odniósł się senator Żaryn. Powiedział m.in., że [...] najgtębsza intencja wnioskodawców [...] dotyczaca podjęcia tej uchwaty jest stwierdzenie, że II wojna światowa wybuchta 1 września 1939 r. i nie ma żadnej okoliczności, $w$ zwiazku z która można bytoby tę date zamienić, i że w wyniku tej napaści Niemiec i Zawiązku Sowieckiego na Polskę zginęto co najmniej 60 milionów, a może nawet dużo więcej milionów, osób. To jest konstatacja bardzo ważna, która niesie ze soba także bardzo ważna interpretacje [...], że nie ma pokoju światowego, nie ma pokoju europejskiego bez wolnej i niepodlegtej Polski. I to jest wniosek ptynacy z tamtych wydarzeń historycznych. Jeśli ktoś chce konstruować pokój i nie uwzględniać prawa Polski do suwerenności, to nie tylko się myli, ale jest wspótodpowiedzialny za tak dramatyczne sprawstwo. [...] I druga sprawa, szalenie ważna, która zreszta podkreślamy w projekcie tej uchwaty. Od pierwszego dnia - od 1 września 1939 r. - II wojny światowej towarzyszy jej zbrodnia ludobójstwa. Ta zbrodnia ludobójstwa obejmuje obywateli II Rzeczypospolitej, którzy zostali jej poddani już wówczas, 1 września 1939 r. I także to ma wybrzmieć w tejże naszej uchwale $e^{47}$. W głosowaniu nad uchwałą wzięło udział 65 senatorów, wszyscy byli za. Senat RP podkreślił, że wydarzenia z 1 września 1939 r., tj. atak Niemiec na Wieluń, miasto na zachodniej granicy przedwojennej Polski, oraz ostrzelanie polskiej placówki wojskowej w Gdańsku na Westerplatte przez niemiecki pancernik Schleswig-Holstein rozpoczęły atak nazistowskich Niemiec na Polskę, a tym samym II wojnę światową. Izba oddała część pamięci wszystkich polegtych, zabitych $i$ innej formie represjonowanych obywateli Odrodzonej Polski w latach 1939-194548.

Analizując wyżej przywołane uchwały, jak też porównując je to tych uchwalonych z okazji 70. rocznicy wybuchu II wojny światowej, należy zauważyć, że sposób narracji Sejmu i Senatu RP bardziej wpisuje się w kształtowanie polityki pamięci na poziomie międzynarodowym niż krajowym. Świadczy o tym szeroki kontekst parlamentarnej

45 Zapis stenograficzny. Posiedzenie Komisji Ustawodawczej (351.) $w$ dniu 31 sierpnia 2019 r., [online] https://www.senat.gov.pl/download/gfx/senat/pl/senatkomisjeposiedzenia/8375/stenogram/351u_ egz_2.pdf, 19 X 2020.

46 Sprawozdanie Komisji Ustawodawczej o projekcie uchwaty w sprawie upamiętnienia 80. rocznicy wybuchu II Wojny Światowej (druk nr 1288), Druk nr 1288 S z 31 sierpnia 2019 r., [online] https://www. senat.gov.pl/download/gfx/senat/pl/senatdruki/10495/druk/1288s.pdf, 19 X 2020.

47 Sprawozdanie Stenograficzne z 84. posiedzenia Senatu Rzeczypospolitej Polskiej w dniach 30 i 31 sierpnia 2019 r., [online] https://www.senat.gov.pl/download/gfx/senat/pl/senat_przebieg_stenogramy_ pdf/368/spr_84net.pdf, 19 X 2020.

48 Uchwata Senatu Rzeczypospolitej Polskiej z dnia 31 sierpnia 2019 r. w sprawie upamiętnienia 80. rocznicy wybuchu II Wojny Swiatowej, „Monitor Polski” 2019, poz. 786. 
narracji, która rozpoczyna się od wskazania na miasto Wieluń, zaatakowanego przez Niemcy 1 września 1939 r. o 4.40. Warto podkreślić, że atak na Wieluń - jako miasto, gdzie rozpoczęła się II wojna światowa (a nie na Westerplatte) - zajmuje ważne miejsce w polityce pamięci Prawa i Sprawiedliwości po wyborach parlamentarnych w 2015 r., kiedy ugrupowanie przejęło władzę. Zauważmy przy tym, że w 2020 r. prezydent Andrzej Duda - popierający politykę pamięci partii rządzącej - odebrał akt Honorowego Obywatelstwa Wielunia jako wyraz wdzięczności za starania o przywrócenie historycznej pamięci o wydarzeniach w tym mieście.

Celem przyjętych przez Sejm i Senat RP w 2019 r. uchwał (jak już odnotowałem wyżej - podobnych w swojej treści) było upamiętnienie wybuchu wojny oraz uczczenie pamięci poległych, zamordowanych, represjonowanych Polaków (żołnierzy i ludności cywilnej) w latach 1939-1945. W upamiętnianiu tym trudno odnaleźć narracje marginalne i alternatywne. Trudno uznać za takie symboliczne akty pamięci o polskich obywatelach, obrońcach ojczyzny, którzy ponieśli śmierć. Pamięć o nich jest nie tylko ważnym elementem polityki pamięci, ale także ma znaczenie dla kształtowania tożsamości wspólnoty narodowej. Parlamentarne narracje o 80. rocznicy wybuchu II wojny światowej - podobnie jak te sprzed dekady - wskazują na Polskę i Polaków jako ofiary nazistowskich Niemiec i Związku Sowieckiego. Należy jednak zauważyć, że w 2019 r. uchwałodawcy inaczej rozłożyli akcenty, tj. zdecydowanie więcej uwagi poświęcili Niemcom, podkreślając chociażby działanie na okupowanym terytorium Polski niemieckich obozów koncentracyjnych i zagłady. Można przyjąć - biorąc pod uwage przytoczone wyżej zarzuty formułowane przez Prawo i Sprawiedliwość wobec polityki pamięci Platformy Obywatelskiej (w tym rządu Donalda Tuska) - że parlamentarna narracja o winie Niemiec i jej wyeksponowanie była tu działaniem celowym. Co ciekawe, w uchwałach nie odnajdujemy deklaracji czy wezwania do pojednania, zgody, wybaczenia win. Na marginesie dość wspomnieć, że to po 2015 r. w dyskursie publicznym za sprawą Prawa i Sprawiedliwości pojawił się problem reparacji wojennych od Niemiec.

Charakterystyczne dla polityki pamięci Prawa i Sprawiedliwości jest eksponowanie roli powstania warszawskiego, które zostało odnotwane w uchwałach Sejmu i Senatu RP upamiętniających 80. rocznicę wybuchu II wojny światowej. Powstanie nazwano symbolem polskiego dążenia do wolności. W rocznicowej narracji nie znalazły się natomiast wątki - jak było w uchwałach podjętych w 2009 r. - podkreślające znaczenie II wojny światowej w budowaniu nowej powojennej Europy opartej na współpracy i demokratycznych wartościach. Treść uchwał w niewielkim stopniu wpisuje się w postpamięciowy dyskurs. Nie ma w nich bezpośrednich odniesień do bólu i wojennej traumy kolejnych pokoleń, podkreśla się za to waleczność Polaków i ich zaangażowanie na wielu frontach wojny. Biorąc pod uwagę formę i treść uchwalonych w 2019 r. uchwat, należy stwierdzić, że trudno uznać je za narracje alternatywne i marginalne, a zatem nieistotne, bez znaczenia dla polityki pamięci, której celem jest wzmacnianie publicznego dyskursu o przeszłości, upamiętnianie postaci i wydarzeń. Niemniej w szerszym kontekście, biorąc przy tym pod uwagę odnotowaną wyżej koncepcję aliansu pamięci i władzy J. Assmanna, państwowe narracje o przeszłości, niejednokrotnie upolitycznione, 
mogą być nie tylko polemiczne, ale także uznane za alternatywne. Jest to zresztą jeden z zarzutów, który formułowany jest wobec uchwał rocznicowych Sejmu i Senatu RP, szczególnie gdy uchwalane są one w drodze głosowania, a nie poprzez aklamację.

Przyjęcie przez Sejm i Senat RP uchwał upamiętniających 80. rocznicę wybuchu II wojny światowej zostało odnotowane w polskich mediach, niemniej nie były one asumptem do szerokich dyskusji czy formułowania komentarzy i ocen w polskim dyskursie medialnym.

\section{UWAGI PODSUMOWUJĄCE}

Bez wątpienia narracje o II wojnie światowej zajmują ważne miejsce w polskim dyskursie publicznym. Są przedmiotem badań naukowych, licznych dyskusji, kontrowersji i sporów - w tym tych o charakterze politycznym. Uchwały rocznicowe jako akty symboliczne i mechanizm polityki pamięci pełnią różne funkcje - upamiętniają postacie i wydarzenia, mogą przywracać i porządkować pamięć, rozliczać przeszłość, wskazywać sprawców i ofiary czy legitymizować lub delegitymizować określony ład. Podlegają także politycznej instrumentalizacji. Stąd też, z punktu widzenia władzy politycznej, uchwały rocznicowe same w sobie nie są w moim przekonaniu narracjami alternatywnymi i marginalnymi. Wyrażają bowiem przekonanie władzy o jej wizji przeszłości. Mają one potencjał nie tylko w zakresie kształtowania pamięci zbiorowej, ale także używania przeszłości jako oręża walki politycznej. Ujawnia się tu Assmannowy koncept sojuszu pamięci i władzy. W tym aspekcie spory o wizje przeszłości mogą dostarczać argumentów o konstruowaniu przez władzę nowej narracji o przeszłości, niekiedy alternatywnej i marginalnej w stosunku do tej powszechnie przyjętej, będącej wynikiem badań historycznych mających oparcie w źródłach czy opowieściach świadków historii - istotnych w perspektywie postpamięciowej refleksji, przypisującej pamięci wartość poznawczą.

Twierdzę jednak, że polityczne spory o przeszłość znacznie redukują wartość poznawczą pamięci, szczególnie gdy intencją spierających się jest jej zawłaszczanie czy co widoczne w ostatnich latach - wysiłki na rzecz jej nacjonalizacji w imię obrony prawdy historycznej. Nie ulega natomiast wątpliwości, że tragizm II wojny światowej, indywidualne i zbiorowe cierpienie oraz trauma milionów ludzi - czasu wojny i kolejnych pokoleń - zasługuje na stałe miejsce w polskiej, europejskiej i światowej pamięci. Różnorodne akty kommemoratywne, w tym uchwały rocznicowe, winny służyć pielęgnowaniu tej pamięci. Celem parlamentarnych narracji upamiętniających 70. i 80 . rocznicę wybuchu II wojny światowej było przede wszystkim przypomnienie o tragicznych wydarzeniach oraz oddanie hołdu i czci poległym. Stwierdzić należy, że pamięć o wydarzeniach, a nade wszystko upamiętnienie poległych, nie są narracjami alternatywnymi i marginalnymi, gdyż stanowi to jedną z najistotniejszych form umacniania pozycji państwa. 


\section{BIBLIOGRAFIA}

\section{Akty prawne}

Uchwata Sejmu Rzeczypospolitej Polskiej z dnia 28 sierpnia 2009 r. w 70. rocznicę wybuchu II wojny światowej, „Monitor Polski” 2009, nr 55, poz. 766.

Uchwata Sejmu Rzeczypospolitej Polskiej z dnia 30 sierpnia 2019 r. w sprawie upamiętnienia 80. Rocznicy wybuchu II Wojny Światowej, „Monitor Polski” 2019, poz. 846.

Uchwata Senatu Rzeczypospolitej Polskiej z dnia 23 września 2009 r. w 70. rocznice wybuchu drugiej wojny światowej, „Monitor Polski” 2009, nr 63, poz. 832.

Uchwata Senatu Rzeczypospolitej Polskiej z dnia 31 sierpnia 2019 r. w sprawie upamiętnienia 80. rocznicy wybuchu II Wojny Światowej, „Monitor Polski” 2019, poz. 786.

\section{Projekty uchwal}

Projekt uchwaty w 70. rocznice wybuchu II wojny światowej, Druk nr 2291 z 28 sierpnia 2009 r., [online] http://orka.sejm.gov.pl/Druki6ka.nsf/wgdruku/2291/\$file/2291.pdf.

Projekt uchwaty w 70. Rocznicę wybuchu Drugiej Wojny Światowej, Druk nr 643 z 8 września 2009 r., [online] https://www.senat.gov.pl/prace/posiedzenia/tematy,222,1.html.

Projekt uchwaty w sprawie upamiętnienia 80. Rocznicy wybuchu II Wojny Światowej, Druk nr 3800 z 30 sierpnia 2019 r., [online] https://orka.sejm.gov.pl/Druki8ka.nsf/0/AACDE7D99ADEFC65C1258466005B30F9/\%24File/3800.pdf.

Projekt uchwaty w sprawie upamiętnienia 80. rocznicy wybuchu II Wojny Światowej, Druk nr 1288 z 30 sierpnia 2019 r., [online] https://www.senat.gov.pl/download/gfx/senat/pl/ senatdruki/10483/druk/1288.pdf.

\section{Sprawozdania stenograficzne}

Sprawozdanie Komisji Ustawodawczej i Komisji Spraw Zagranicznych (wraz z zestawieniem wszystkich wniosków) o projekcie uchwaty $w 70$. rocznice napaści przez Rosje i Niemcy na Polskę, Druk nr 642 O z 22 września 2009 r., [online:] http://ie.senat.gov.pl/k7/dok/ $\mathrm{dr} / 600 / 6420-$ poprawiony.pdf.

Sprawozdanie Komisji Ustawodawczej oraz Komisji Spraw Zagranicznych o projekcie uchwaty w 70. Rocznicę napaści przez Niemcy i Rosję na Polskę, Druk nr 642 z 8 września 2009 r., [online] http://ww2.senat.pl/k7/dok/dr/600/642o.pdf.

Sprawozdanie Komisji Ustawodawczej i Komisji Spraw Zagranicznych (wraz z zestawieniem wszystkich wniosków) o projekcie uchwaty w 70. Rocznice wybuchu Drugiej Wojny Światowej, Druk 643 z 22 września 2009 r., [online] http://ie.senat.gov.pl/k7/dok/dr/600/643o.pdf. Sprawozdanie Komisji Ustawodawczej o projekcie uchwaty w sprawie upamiętnienia 80. rocznicy wybuchu II Wojny Światowej (druk nr 1288), Druk nr 1288 S z 31 sierpnia 2019 r., [online] https://www.senat.gov.pl/download/gfx/senat/pl/senatdruki/10495/druk/1288s.pdf. Sprawozdanie Stenograficzne z 84. posiedzenia Senatu Rzeczypospolitej Polskiej w dniach 30 i 31 sierpnia 2019 r., [online] https://www.senat.gov.pl/download/gfx/senat/pl/senat_przebieg_stenogramy_pdf/368/spr_84net.pdf. 
Zapis stenograficzny. Posiedzenie Komisji Ustawodawczej (351.) w dniu 31 sierpnia 2019 r., [online] https://www.senat.gov.pl/download/gfx/senat/pl/senatkomisjeposiedzenia/8375/ stenogram/351u_egz_2.pdf.

Zapis stenograficzny (1098) ze wspólnego posiedzenia Komisji Spraw Zagranicznych (85.) oraz Komisji Ustawodawczej (227.) w dniu 22 września 2009 r., [online:] http://ww2.senat.pl/ $\mathrm{k} 7 / \mathrm{kom} / \mathrm{ksz} / 2009 / 085 \mathrm{sz} . \mathrm{htm}$.

\section{Dokumenty}

Program PiS 2014, [online] http://pis.org.pl/dokumenty?page=2.

\section{Opracowania monograficzne}

Assmann J., Pamięć kulturowa. Pismo, zapamiętywanie i polityczna tożsamość w cywilizacjach starożytnych, red. R. Traba, przel. A. Kryczyńska-Pham, Warszawa 2008.

Hirsch M., Family Frames. Photography, Narrative and Postmemory, London 1997.

Kaniowska K., Postpamięć, [w:] Modi memorandi. Leksykon kultury pamięci, red. M. Saryusz-Wolska, R. Traba, współpr. J. Kalicka, rada nauk. P. Czapliński [i in.], Warszawa 2014.

Kertzer D.I., Ritual, Politics and Power, New Heaven-London 1988.

Kwiatkowski P.T., Nijakowski L.M., Szacka B., Szpociński A., Między codziennościq a wielka historia. Druga wojna światowa w pamięci zbiorowej spoteczeñstwa polskiego, Gdańsk-Warszawa 2010.

Machcewicz P., Muzeum, Kraków 2017.

Machcewicz P., Spory o historię 2000-2011, Kraków 2012.

Main I., Trudne świętowanie. Konflikty wokót obchodów świąt pañstwowych i kościelnych w Lublinie (1944-1989), Warszawa 2004.

Napiórkowski M., Powstanie umartych. Historia pamięci 1944-2014, Warszawa 2016.

Nijakowski L.M., Polska polityka pamięci. Esej socjologiczny, Warszawa 2008.

Secler B., Odzyskanie niepodlegtości w uchwatach rocznicowych Sejmu i Senatu RP, [w:] Polska po latach niewoli, red. R. Kowalczyk, Łomża 2018.

Secler B., Polityka historyczna VIII kadencji Sejmu RP - nowe otwarcie? Przyktad podjetych uchwat rocznicowych (listopad 2015-lipiec 2016), [w:] Na obrzeżach polityki. Praca zbiorowa. Cz. 11, red. M. Kosman, Poznań 2017.

Szacka B., Pamięć spoteczna a identyfikacja narodowa, [w:] Trudne sąiedztwa. Z socjologii konfliktów narodowych, red. A. Jasińska-Kania, Warszawa 2001.

Wolff-Powęska A., Rocznice historyczne jako medium polityki pamięci, [w:] Na obrzeżach polityki. Praca zbiorowa. Cz. 7, red. M. Kosman, Poznań 2009.

\section{Artykuły naukowe}

Hirsch M., Pokolenie postpamięci, przeł. M. Borowski, M. Sugiera, „Didaskalia. Gazeta Teatralna" 2010, vol. 18, nr 105.

Kulas P., Narracja jako przedmiot badań oraz kategoria teoretyczna w naukach spotecznych, „Kultura i Społeczeństwo" 2014, nr 4.

Maroń G., Uchwaty okolicznościowe Senatu w polskim porzadku prawnym, „Przegląd Prawa Konstytucyjnego" 2014, nr 3, https://doi.org/10.15804/ppk.2014.03.12. 
Nijakowski L.M., Uchwaty sejmowe jako mechanizm politykipamięci, „Przegląd Humanistyczny” 2017, vol. 61, nr 2, https://doi.org/10.5604/01.3001.0010.4148.

Radomski A., Badanie narracji historycznej: próba konceptualizacji kulturoznawczej, „Annales Universitatis Mariae Curie-Skłodowska. Sectio F” 2001, vol. 56.

Secler B., Konfliktowe rocznice - wymiar międzynarodowy polskiejpolityki pamięci na przyktadzie wybranych uchwat rocznicowych Sejmu Rzeczypospolitej Polskiej, „Przegląd Humanistyczny” 2017, vol. 61, nr 2, https://doi.org/10.5604/01.3001.0010.4150.

Wolff-Powęska A., Polskie spory o historię i pamięć. Polityka historyczna, „Przegląd Zachodni” 2007 , nr 1.

\section{Internet}

Wolff-Powęska A., Kto wtada nasza pamięcia zbiorową?, [online] http://usf.amu.edu.pl/filmoteka/wykłady-uniwersyteckie/wykład-49-prof-anna-wolff-powęska-kto-włada-nasząpamięcią-zbiorową.

Bartłomiej SECLER - adiunkt w Zakładzie Najnowszej Historii Politycznej na Wydziale Nauk Politycznych i Dziennikarstwa Uniwersytetu im. Adama Mickiewicza w Poznaniu. Członek Polskiego Towarzystwa Nauk Politycznych, Polskiego Towarzystwa Komunikacji Społecznej, Memory Studies Association. Kierownik grantu finansowanego przez Narodowe Centrum Nauki: „Miejsce i rola uchwał rocznicowych Sejmu i Senatu RP w polskiej polityce pamięci” (OPUS $13 \mathrm{nr}$ rej. 2017/25/B/HS5/01425). Wykonawca w międzynarodowym projekcie badawczym: „Journalistic Role Performance (JRP) Study: Second Wave". Kierownikiem projektu jest prof. Claudia Mellado (School of Journalism, Pontificia Universidad Catolica de Valparaiso, Chile). Zainteresowania naukowe: rocznice historyczne, uchwały rocznicowe Sejmu i Senatu RP, polityka pamięci, historia polityczna Włoch, ewolucja włoskiej sceny politycznej, badania nad dziennikarstwem. 